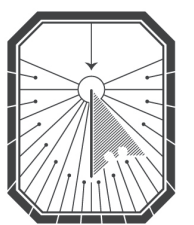

KYIV-MOHYLA

LAW \& POLITICS JOURNAL

KYIV-MOHYLA SCHOLARLY PEER-REVIEWED JOURNALS

Characteristics of Advocacy under Different Freedom Regimes: Belarus, Ukraine, and Lithuania

Author(s): Svitlana Batsyukova

Source: Kyiv-Mohyla Law and Politics Journal 6 (2020): 139-158

Published by: National University of Kyiv-Mohyla Academy

http://kmlpj.ukma.edu.ua/ 


\title{
Characteristics of Advocacy under Different Freedom Regimes: Belarus, Ukraine, and Lithuania
}

\author{
Svitlana Batsyukova \\ World Bank Consultant, Ukraine
}

\begin{abstract}
This article presents a comparative analysis of the characteristics of advocacy in three countries with different levels of political and civil freedom. This analysis correlates each country's freedom level with the characteristics of its advocacy activities. The analysis's results are based on interviews of experts conducted from 2015 through 2017 in unfree Belarus, partly free Ukraine, and free Lithuania. The analysis focuses on the following advocacy characteristics: its scale; its agents and targets; its goals; the extent to which it sought to protect rights, freedoms, and other interests, its promotion of ideas; and its results.
\end{abstract}

Key Words: advocacy, freedom status, characteristics of advocacy, Ukraine, Lithuania, Belarus

\section{(2)}

Advocacy can exist in every country. The country need not be democratically governed or friendly to liberal rights and freedoms. Advocacy can exist even in authoritarian, repressive countries where governmental respect for fundamental political rights and civil liberties from low to nonexistent. These were the conclusions of the learning-exchange session "Advocacy in Society" at the 2016 Frontiers of Democracy conference at Boston's Tufts University. ${ }^{1}$

Drawing on these conclusions, this article analyses advocacy in countries that have different freedom statuses, meaning different levels of freedom. As used here, "advocacy" means a "complex of interconnected actions aimed at [the] promotion of idea[s] or action, and [the] protection of rights and interests ... that targets [the] decision making process or politics in general through [the] activization of citizens." 2 "Freedom status" is a measure of a country's freedom developed by Freedom House, an international nongovernmental organization. ${ }^{3}$ A country's freedom status is

1 "Civic Leaders explore the Frontiers of Democracy," Jonathan M. Tisch College of Civic Life, accessed April 23, 2020, https://tischcollege.tufts.edu/news/civic-leaders-explore-frontiersdemocracy.

2 Svitlana Batsyukova, "Defining Advocacy as a Subject for Research in Political Science," Infobulletin of Kharkiv National University. Series "Issues of Political Science" 27 (2014): 77-82. "Freedom in the World Research Methodology," Freedom House, accessed April 23, 2020. https:// freedomhouse.org/sites/default/files/2O2O-O2/Methodology_FIW_2019_for_website.pdf. 
determined by two elements: the political rights and civil liberties actually enjoyed by that country's residents. These rights and liberties are largely derived from the Universal Declaration of Human Rights and influence the opportunities for creating and maintaining democracy in a country. Freedom House's Freedom in the World Report annually ranks countries by the political rights and civil liberties enjoyed by their respective populations. Countries are ranked as "free," "partly free," and "not-free." People in a "free" country do not necessarily enjoy perfect freedom or a full spectrum of civil liberties. However, they enjoy comparatively more freedom than those in who live in countries ranked as "partly free" or "not free."

Because it uses criteria drawn from the Universal Declaration of Human Rights, this methodology can be appropriately used worldwide. Freedom status is not culturally, gender, or religiously biased. The rights and freedoms it measures are contingent on the expression of civic will, the opportunity to exercise rights and freedoms, the opportunity to influence decision making, and the like. ${ }^{4}$ These activities are integral parts of advocacy and advance democracy.

Democracy depends on relatively high levels of political rights and civil liberties. In other words, it depends on civic activism and the ability of a country's population to advocate for or against various rights, interests, the ideas. Thus, advocacy and its characteristics are central to ranking countries as free, partly free, and not-free.

To explore advocacy characteristics in Ukraine, Belarus, and Lithuania, in 2016 the author conducted nine detailed interviews with seven experts who were experienced in advocacy planning and implementation. Some were academics with a strong understanding of and experience in advocacy. Others were leaders, promoters, and participants of advocacy movements in Lithuania, Ukraine, and Belarus.

The characteristics of advocacy in Belarus were identified and discussed in interviews with the following experts ${ }^{5}$ :

- Ms. Anna Gerasimova, a human rights protection specialist and the Director of the Belarusian Human Rights House in Vilnius, Lithuania;

- Ms. Tatiana Revyaka, a human rights protection specialist with the Center "Vyasna" in Minsk, Belarus; and

- Mr. Florian Irminger, the Head of Advocacy at the Human Rights House Network in Geneva, Switzerland.

The advocacy characteristics in Lithuania were analyzed based on interviews with the following experts:

- Dr. Vytis Jurkonis, a Professor at the Vilnius National University, an expert on Lithuanian Foreign Policy, and the Project Director at Freedom House in Vilnius, Lithuania;

- Dr. Nerijus Maliukevičius, a Professor at the Vilnius National University and an expert on Politics and Media in Vilnius, Lithuania;

4 Svitlana Batsyukova, "Freedom Status as a Reflection of Existence of Advocacy in Society," Academic journal "POLITICUS" (2017): 44-46.

5 Svitlana Batsyukova, "Characteristics of Advocacy in Current Belarus," Info-bulletin of Lviv University. The series of Philosophy and Political Studies 11 (2017): 111-16. 
- Ms. Anna Gerasimova, the Director of the Belarusian Human Rights House in Vilnius, Lithuania;

- Mr. Florian Irminger, the Head of Advocacy at the Human Rights House Network in Geneva, Switzerland.

- The characteristics of advocacy in Ukraine were described during these interviews:

- Mr. Ruslan Kraplych, an advocacy expert and the Head of the Board of the Ostroszky Foundation in Rivne, Ukraine;

- Mr. Serhiy Burov, an expert at the Network of the Human Rights Houses, Chernihiv, Ukraine;

- Mr. Florian Irminger, Head of Advocacy, Human Rights House Network, Geneva, Switzerland.

English, Ukrainian, or Russian was used to conduct interviews, at the choice of the interviewee. On average, each interview lasted an hour and was recorded with the interviewee's permission.

The interview questions were as follows:

1) How massive is advocacy in Lithuania, Belarus, or Ukraine?

2) Is advocacy based on the promotion of interests, the protection of rights and freedoms, or the promotion of new ideas?

3) What is the goal of the advocacy?

4) What are the targets and who are agents of the advocacy?

5) What is the level of advocacy implementation: local, national, or international?

\section{Belarus}

\section{The Scale of Advocacy in Belarus}

In this article, the scale of advocacy is based on the motivation and ability of civil society groups to cooperate in their advocacy and to combine their efforts while expanding the scale of advocacy. A previous study of the solidarity potential in Belarusian civil society ${ }^{6}$ suggests that there is a low ability of the citizens to carry out joint political or social activities or to protect the public interest. That study shows that, despite the increase in the number of petitions, public statements, and the collection of signatures (as advocacy instruments), those advocacy instruments have a weak mobilization potential and do not lead to structural changes. The low solidarity potential of Belarusian civil society also shows indirectly that even if advocacy activities are in place, they are constrained and are unable to transform into mass movements on the national level.

According to Belarus's freedom status, political rights and civil liberties in Belarus remain unprotected. Because its freedom index is 19 out of 100, Belarus is a "not free"

6 "Research on the Potential of Solidarity in Belarusian Civil Society," Belarusian Institute of Strategic Studies, accessed April 24, 202O. http://cet.eurobelarus.info/files/userfiles/5/ CET/2014_Solidarity_NGOs_Belarus.pdf. 
country. ${ }^{7}$ In "not free" Belarus, changes are possible. Therefore, advocacy activities are possible too, provided they do not relate to civil and political rights. Among the examples listed by the experts interviewed, the campaigns for promotion of the Belarusian language are quite noticeable, including, for example the online campaign promoted at www.talaka.by. ${ }^{8}$ Also, new ideas as fundraising organized by the Belarusians to assist emigrants fleeing from Ukraine had a great popularity and effectiveness in 2014 and 2015. Due to the political situation in Belarus and the repressive character of its legislation, achieving a high level of solidarity is impossible. Consequently, organizations assisting disabled persons, children, and those who suffer from family violence often refuse to cooperate with the human rights groups and consider their circumstances as falling outside of human rights protection. And human rights advocacy groups, in turn, experience difficulties cooperating with other civil society organization.

\section{The Place of Interests, Values, and Rights in Advocacy in Belarus}

According to experts' estimates, growth in public activity and solidarity is observed only sporadically. These experts report that advocacy in Belarus is based on both the promotion of interests consolidated communities and social groups and the protection of rights. For example, when a crackdown of the "Ploshcha" took place in Minsk, ${ }^{9}$ people, regardless of their political affiliations, supported its victims financially and wrote requests to the President, to the Prosecutor's Office, and to law-enforcement bodies. In this instance, however, the experts interviewed commented that the reaction to the crackdown was more about values and interests than about human rights.

According to Anna Gerasimova, advocacy movements in Belarus aimed at protecting rights involve well-known public figures who are most trusted, liked, and sympathized with by the society. In recent years, such movements emerged in protests against the deportation of the human rights advocate Yelena Tolkacheva and against the arrest of the human rights advocate Ales Belyackiy.

\section{The Agents and Targets of Advocacy in Belarus}

Advocacy agents in Belarus are interested groups. Those interested groups are often joined by activists who help to make advocacy more systemic. Rarely are the employees of state-funded organizations - health workers, teachers, employees of other public institutions, and the like - advocacy agents because they risk losing their jobs.

Belarusian students, when promoting their interests, are often passive advocacy agents. In 2008, students made a stand against cancellation of their travel benefits, and

“Freedom in the World 2019. Belarus," Freedom House, accessed April 25, 2020. https:// freedomhouse.org/country/belarus/freedom-world/2019.

8 "Seven Facts about Talaka", Talaka, accessed April 25, 2021. https://www.talaka.org/.

9 “Freedom Day in Belarus," Ukrainska Pravda, accessed April 25, 2020. http://www.pravda.com. ua/news/2017/03/25/7139266/. 
in November and December 2015, they turned against the act providing for the paid retaking of tests at universities. Probably, because of the low solidarity potential as described in the section "Massiveness of advocacy activities in Belarus," the students never asked for help from society.

In Ukraine, people directly affected by a problem and members of civil society in general become advocacy agents. In Lithuania mainly the persons and organizations whose interests or rights are violated become the advocacy agents. Targets for advocacy in Belarus are representatives of authorities. For example, during a student campaign of 2015, the students tried to explain their position to the rector of a university and make a deal with him. But the rector refused to talk to them. Anna Gerasimova's assessment of this advocacy campaign revealed that the campaign goals were incorrectly set, and the campaign did not aim at achieving structural changes. For example, students could have proceeded from the fact that education, in accordance with the Constitution of the Republic of Belarus, is free of charge and thus test retaking should be free. But the campaign's goals were presented as if they were serving only mercantile interests and were needed solely for those students who performance lagged. Accordingly, the campaign's targets did not react to the students' protests.

\section{The Goals of Advocacy in Belarus}

Advocacy is a complex of actions aimed at promoting an idea or action to protect rights and interests. It targets decision making processes or politics in general by mobilizing citizens. ${ }^{10}$ Improving the quality of life is the most common goal for advocacy in Belarus.

According to experts, because the advocacy goals in Belarus are not always clearly formulated or understandable, protest movements often fail to get support from NGOs or political parties. For example, in 2011, as the result of the rapid currency devaluation, people lost their savings and took to the streets. But the organizations did not support them because the advocacy objectives at that moment were not clearly formulated and there was an impression that advocacy was organized for the sake of the protest itself rather than for a purpose of securing systemic change.

A massive advocacy movement in Belarus in March 2017 as part of Freedom Day aimed at showing dissatisfaction with the law against Labor Parasitism ('Darmoyedstvo') and with the economic situation in the country ended up in numerous "preventive" arrests of the protesters, which, in turn, led to more protest actions in several Belorussian cities. ${ }^{11 T h e}$ actions that followed these preventive arrests involved various strata of the people and not only those who disagreed with implementation of the Act. As this example shows, the outcomes of an advocacy movement can formulate the goal and objectives of a subsequent advocacy campaign.

10 Batsyukova, "Defining advocacy," 77-82.

11 "Arrests are happening again in Minsk," Ukrainska Pravda, accessed April 25, 2020. http://www. pravda.com.ua/news/2017/03/25/7139266/. 


\section{The Level of Advocacy Implementation in Belarus}

Unlike in partly-free Ukraine, the protection of human rights in not-free Belarus is overly politicized. Consequently, advocacy activities aimed at protecting human rights are unsuccessful and often impossible at the national level. Being unable to implement human rights advocacy initiatives at the national level, as Florian Irmigner stated, Belarusian activists achieve effective results at the international level. For example, campaigns aimed at freeing political prisoners in Belarus became widely known thanks to the efforts of Belarusian human rights advocates, as was emphasized in a report of the UN Special Rapporteur on Belarus, Miklós Haraszti. ${ }^{12}$

The level of implementation of advocacy in Belarus mainly depends on the target group and the interests for which protection is sought. Advocacy at the local level in Belarus is not widespread or influential. In clarifying the reasons for this, Tatiana Revyaka explained the procedure for appointing heads of districts. District heads are appointed by the President. Officials take no decisions that could lead to structural changes. Even amending a locality's master plan which might prompt (e.g. protests against construction or petitioning in favor of local planning), often cannot be considered at the local level if master plan was approved at the national level. As it is further explained in the section "Agents and Targets of Advocacy in Belarus", officials are often unable and not motivated to challenge the position at the national level.

\section{Ukraine}

\section{The Scale of Advocacy in Ukraine}

Ukraine is a partly-free country according to its Freedom in the World 2019 ranking of 6o out of 100.13 Starting from 1990s, Ukraine has had several "maidans", the best known of which were the Student, Ukraine without Kuchma, Language, and Tax Maidans, plus the Orange Revolution and the Revolution of Dignity. These "maidan" movements stemmed from, inter alia, the traditions in the development of the Ukrainian society. These included a sense of injustice, the rejection of "unfreedom", defiance, a lack of trust of authorities, and the like. The sense of injustice in the Ukrainian society is one of the most important factors, ${ }^{14}$ and it emerges irrespective of whether we know persons whose interests or rights were violated or not.

Some researchers say that a new Ukraine was born on the Maidan. Advocacy movements during the Revolution of Dignity not only replaced government but also

"Belarus: Unchanged Oppression of Human Rights Necessitates Continuation of UN Mandate, Special Rapporteur Says," United Nations Human Rights Office of the High Commissioner, accessed November 28, 2018. http://www.ohchr.org/EN/NewsEvents/. 
changed people's behavior and views. ${ }^{15}$ The Revolution of Dignity featured massive protests against a dictatorship and corruption. Contemporary advocacy campaigns in Ukraine are characterized by the massive involvement and representation of various groups of the population.

According to Serhiy Burov's interview, massive involvement in advocacy in Ukraine in the post-Maidan period (Revolution of Dignity, 2013-2014) may be rated as "7" on a scale from one to ten, because more opportunities for appeal to the power holders with various requests. In Ruslan Kraplych's opinion, Ukrainian authorities are more receptive to the requests from the centers, groups, and the like if they are supported by mass events (e. g.organized demonstration, petitions, and the like). In March 2015, with action launched in Chernihiv and Vinnytsia regions, business associations required cancellation of the Verkhovna Rada resolution based on the submission from the Cabinet of Ministers of Ukraine, as regards introduction of cash-register machines in small and medium companies. About one hundred business associations, through their advocacy campaign, successfully pressured the Rada to cancel its resolution on introduction of cash-register machines in July 2015. Generally, the businesses were not against the cash-register machines. They demanded that any laws and resolutions affecting small and medium businesses must be supported by business associations at least a half a year in advance of law or resolution becoming effective. They also called on the government to announce in advance the actions it intended to take to improve the business climate in Ukraine.

In 2016, a massive campaign by the members of the agrarian industry (farmers, agrarian enterprises and business associations) against a draft amendment to the Tax Code (concerning cancellation of a Single Tax) began. As the result of numerous protests and internet-based actions, in late 2015, the state budget for 2016 was approved without amending the tax legislation.

\section{The Place of Interests, Values, and Rights in Advocacy in Ukraine}

According to the advocacy expert Ruslan Kraplych, promoting interests is the predominant factor of advocacy in Ukraine. Protecting rights and freedoms is second, and promoting new ideas is third. New ideas mainly concern reallocating resources in local budgets and ensuring their transparency. The freer the society becomes, the opportunities to introduce new ideas increase, and the need for protect rights and interests decrease. The three experts interviewed placed protecting interests as the leading basis for advocacy in contemporary Ukraine, with protecting values, rights, and ideas, in the remaining three places in that order.

During the Revolution of Dignity, when Ukraine was rated lower for realization of rights and freedoms than it is now, the realization of rights and freedoms was the top priority and was a motivating factor (basis) for advocacy. Realizing ideas was in second place, and promoting interests was in third place.

15 Nadia Diuk, "Finding Ukraine," Journal of Democracy. The Maidan and Beyond. 25, no. 3 (2014): $83-90$. 
In line with Florian Irmigner's interview responses, in the context of changes, new ideas emerge as the result of the changes in the political situation. In 2015 and 2016, the favorable political situation made it possible to draft the National Strategy on Human Rights $^{16}$ and the National Action Plan for implementation of the National Strategy on Human Rights. Due to the political situation, other ideas lost their edge and priority. Thus, as Serhiy Burov stated, an idea about introducing "school policemen" lost its immediacy because of the unfinished police reform.

In 2015 and 2016, the NGO "M'ART", in Chernihiv, Ukraine, actively protected interests of those who took part in the Anti-Terroristic Operation (ATO) and did not gain the benefits the ATO veterans were entitled to under the law, including, for example, travel privileges andland plots. Because of the problems the target group had repeatedly faced, M'ART decided to publish a booklet explaining the ways ATO veterans could obtain various services and benefits. These included, for example, how they could gain possessory rights to property in the ATO zone, obtain a land plot, register deaths or births, obtain financial assistance, or cross the demarcation line. As Serhiy Burov suggested, giving land plots to the families of the soldiers killed in the ATO proved to be a complicated process for the organization because of the resistance from the village councils, as occurred near the Novoselivka village in the Chernihiv oblast. The conflict was resolved by using land owned by the Institute of Microbiology, which satisfied both the interests of the village councils and families of the soldiers killed in ATO.

\section{The Agents and Targets of Advocacy in Ukraine}

In Ukraine, advocacy agents are people directly affected by a problem and members of civil society in general who have not faced that problem but are able to assist with solving it.

In Serhiy Burov's opinion, the protection of interests as the basis for advocacy is dominant in contemporary Ukraine because many groups need their interests protected. Among those groups are the participants in the Anti-Terrorist Operation (ATO) and their families and internally displaced persons. Those groups have emerged in the wake of the humanitarian crisis and are both agents and targets of advocacy.

For example, internally displaced people promote their interests by themselves and with the assistance of the other organizations that have a long history of protecting rights and freedoms (similar to the granting of land plots to the families of the soldiers killed in ATO). Internally displaced persons cannot take part in local decision-making processes to the same degree as those persons who permanently live in that territory. Resettled people often try to promote their interests individually. As Serhiy Burov points out in his interview, groups of resettled people can individually support themselves and protect their interests; therefore, they are advocacy agents.

16 Law od Ukraine "On the Adoption of the National Strategy on Human Rights," accessed April 25, 2020. http://zakon3.rada.gov.ua/laws/show/501/2015. 
In opinion of Florian Irminger, an expert at the Human Rights House Network, Ukrainian authorities are the targets for the national and local advocacy. Often, Ukrainian authorities also become advocacy agents at the international level. Any organization, group, coalition etc. may become an advocacy agent without difficulties. In 2015 and 2016, in the process of approving (August 2015) and adopting (January 2016) of the National Strategy on Human Rights, the Ministry of Justice of Ukraine approached NGOs to establish the working group to work on the Strategy at the national level.

In Ruslan Kraplych's expert opinion, Ukrainian society does not respond to the interests of small groups. Therefore, the protection of the private companies' interests is more effective through associations that serve as advocacy agents.

Petitions as the advocacy instruments are becoming more popular for introducing changes at the local level in Ukraine. They have little impact, however, unless they are transformed into a local initiative. Voters are the advocacy agents, and local councils and deputies respond to proposed changes and become targets of advocacy.

\section{The Goals of Advocacy in Ukraine}

Influencing decision-making that results in legislative and regulatory acts, the reallocation of local budgets, and the like are often goals for advocacy in Ukraine. For example, libraries in Ukraine had tried to prevent their liquidation for a long time and sought increases in librarian salaries through the reallocation of funds in local budgets. Advocacy was successful; local officials reallocated their budgets to provide the funds needed to support libraries. As a result, the salaries of librarians in Ukraine are now higher, for example, than the salaries of the workers in other cultural institutions.

In Ruslan Kraplych's opinion, achieving advocacy goals often depends on whether the advocacy targets have been chosen correctly. Advocacy in contemporary Ukraine works for the protection of interests (including those economically feasible and efficient) of a social group, a community, or the society at large.

In his interview, Florian Irminger states that during the period after the Maidan, ensuring that the promises made by the politicians during Maidan are met had become one of the advocacy goals. He compares the process of implementing change (as an advocacy outcome) in the conditions of the "free" freedom regimes and "not free" freedom regimes. He adds, "If you live in a democratic and free country, and you have a draft law which, in one way or another, is in breach of the human rights, it doesn't mean that any changes in respect of non-adoption or repealing of the above draft law will take place very fast. Quite the contrary. One is liable to wait for such changes for a long time. This is because the public should be involved in the debate, and this means a long process. Involvement of the public, society as a whole, in the process of decision-making is a requirement of a democratic regime". Changes in "partly free" or "not free" regimes also require a long time because of the lack of political will, obstacles created by the authorities, or corruption. Being a product of advocacy, changes are difficult to achieve under any regime. 


\section{The Level of Advocacy Implementation in Ukraine}

According to the experts' estimates, advocacy in Ukraine is most widely applied and effectively applied at the national level. The previously mentioned National Strategy on Human Rights the product of national advocacy by NGOs.

According to Florian Irminger's conclusions, an expert at the Human Rights House Network, the advocacy targets are located inside and outside Ukraine. In 2016, Ukraine had around 700 cases related to a suit against Russia that involved events in Crimea and in the East of Ukraine pending in the European Court of Human Rights. These cases are examples of international advocacy. In 2015 and 2016, the political situation in Ukraine led to the establishment of numerous coalitions, including the following:

- The Reanimation Package of Reforms, the largest coalition of leading nongovernmental organizations and experts in Ukraine who have pooled their efforts to facilitate and implement reforms; and

- The Coalition "Justice for Peace in Donbas", an informal union of 17 NGOs and initiatives. Members of the coalition have combined their efforts to document human rights violations committed during the armed confrontation in the Donbas. The coalition protects the interests of the victims of the armed conflict and collects evidence for the Hague Tribunal.

There are also international coalitions created between the NGOs in Ukraine and Russia. For example, Ukraine is represented by the Crimean Field Mission, and Russia is represented by the Union of Soldiers' Mothers, the Civic Assistance Committee, and other organizations.

As Florian Irminger noted in his interview, advocacy in Ukraine is developing at various levels, and this explains why there are practically no obstacles currently. In the case of Ukraine, the level of advocacy efficiency does not depend on the level of its implementation.

Advocacy at the local level has not had the impact as advocacy at the national level and is limited to certain regions of Ukraine. As explained by Ruslan Kraplych, communities in the Lviv region where the population's main income stems from berry-collecting in the forests have induced oblast authorities into appropriating funds to pay for the certification of organic standards. District administrations in the Odesa region created expert groups in 2015 to complete packages of local regulatory acts. These acts accounted for the communities' interests and were recommended to the village, city, and district councils for them to enact. An example given during the interview with Ruslan Kraplych shows that one of the initiative groups in Odesa region had, by means of advocacy, induced the local department of healthcare into reporting of how number and kind of medicinal products that are available at hospitals. This local initiative was launched to protect the public interest. 


\section{Lithuania}

\section{The Scale of Advocacy in Lithuania}

Lithuania enjoys the implementation of political freedoms and civil liberties (civil liberties $=1$; political freedoms $=1$; aggregate score of freedom $=91$ out of 100 , where 100 is the freest) ${ }^{17}$ Lithuania has a consolidated democracy ${ }^{18}$ and signs indicate that it is consolidating more.

The experts interviewed described advocacy in Lithuania as a "narrow field," meaning it had a narrow circle of advocacy initiatives. They described advocacy there as not massive. All experts stated that the concept of advocacy is not well understood, so all experts referred to the ambiguity of advocacy while describing its scale, agents, targets, and other characteristics. Dr. Nerijus Maliukevičius commented that "lobbying and promotion of corporate interests are often masked in Lithuania as advocacy." He interpreted advocacy as a movement that should "envisage creation of positive legal or political environment."

In these experts' opinion, advocacy is moderately massive in Lithuania. Lithuania is a country of checks and balances. Protests are a very last resort for civil society to show its dissatisfaction. Occasionally there are solidarity actions (moderately extensive). The Polish political body in Lithuania, for example, can assemble groups of teachers, students, and parents but more for political reasons rather than for a genuine ambition to change anything, thus making assembling these groups a political act.

In Dr. Vytis Jurkonis's opinion, massive boycotts and protests are happening mainly in countries where the system of checks and balances is not functioning well. In 2009, when the Lithuanian authorities wanted to change the tax system ${ }^{19}$ and aimed at implementing the politics of savings, it was the last time when Lithuanians protested massively and aggressively (windows of the Parliament were smashed by protestants, tear gas was used against protestants).

Currently, advocacy in Lithuania is peaceful. In 2015 there was a campaign called "Let's Do It" aimed at cleaning local territories. ${ }^{20}$ Society in Lithuania was galvanized through the web, and local communities mapped territories for cleaning. Although the initiative did not promote any political or economic interests, it tackled an important

17 "Freedom in the World 2019. Lithuania", Freedom House, accessed November 25, 2020. https:// freedomhouse.org/country/lithuania/freedom-world/2019.

18 "Nations in Transit 2018. Lithuania," UNHCR, accessed April 27, 2020. https://www.refworld. org/docid/5b3cc27fa.html.

19 Arunas Juska and Charles Woolfson, "Policing political protest in Lithuania," Crime, Law and Social Change no. 57 (2012): 403-24 
social interest/idea — “it is good when it is clean". The campaign did not envisage any aggressive actions and was non-political.

In Dr. Nerijus Maliukevičius's opinion, the Soviet period changed Lithuanian society. Communities lost their abilities to self-organize and protect their interests. Lithuanians were "traumatized" by the apathy developed in Soviet times. Because of this, in his opinion, advocacy in Lithuania is not active.

\section{The Place of Interests, Values, and Rights in Advocacy in Lithuania}

Numerous advocacy campaigns in Vilnius seek to promote interests. A local community of Vilnius, Vilnius's Old Town, which is on UNESCO Heritage List, appealed to local authorities about a building that was too high compared to other buildings, thus violating UNESCO's Heritage Listing requirements. In many cities Lithuanians get together to improve the local infrastructure by seeking and obtaining, for example, pedestrian walking areas and cycling routes that are in the locals' interests.

In her interview, Anna Gerasimova indicated that LGBT issues and interests are on the agenda due to efforts of advocacy groups. As she and the other Lithuanian experts noted, advocacy in the conditions of consolidated democracy in Lithuania is values-based, and Lithuanians no longer take democracy and human rights for granted.

In September 2015, Lithuanians associated with Russian and Polish schools in Lithuania advocated for changes. ${ }^{21}$ The Polish community had three issues: bi-lingual topographic signs, last names in the passport, and education. Polish and Russian minorities in Lithuania tend to raise education issues. Often such advocacy movements are happening when the window of opportunity opens, ad it does in September when schools open and before elections. As described by Vytis Jurkonis when he spoke about protests over schools, Lithuania is the best country for Polish minorities' education because Polish students can study in Lithuania in Polish from their kindergarten through their university education. The Lithuanian authorities' response to requests made by Polish minorities is limited, so protests are becoming more politicized.

Cities like Klaipeda (the port) and Vilnius (the capital), and Visaginas (a city established in 1975 around a nuclear power plant) are populated with Russian minorities who are well integrated and speak Lithuanian. Lithuanian is less widespread among Polish minorities compared to Russian minorities. To actively advocate for their interests, Polish minorities have established a political party based on ethnicity as an agent of advocacy actions.

\section{Agents and Targets of Advocacy in Lithuania}

In some instances, the target for advocacy in Lithuania has been defined as the "environment," meaning the legal and social environment. For example, the advocacy

21 "Protests by the Parliament of Lithuania. What will happen with schools in Vilnius?" RU.DELFI, accessed April 27, 2020. http://ru.delfi.lt/news/live/protest-u-pravitelstva-litvy-chto-budet-soshkolami-vilnyusskogo-kraya.d?id=68125716. 
initiative "White Gloves" (in Lithuanian — "Baltosiospirštinès") aimed at changing the environment of elections by making them more transparent..$^{22}$ The "White Gloves" initiative is not affiliated with a political party. It monitors national elections and reports all unlawful practices to law enforcement agencies. The "White Gloves" employ various tools and initiatives to support Lithuanian civil society to fight political corruption.

Some initiatives seek to improve the legal environment. For instance, when a tax exemption was taken away for printed media in Lithuania, journalists protested. This mainly concerned the interests of journalistic society and made journalists the agents of change (media becomes an advocacy agent when it wants to ally with other groups to promote change).

In other circumstances, journalists act as targets or "instruments" of advocacy (advocacy is conducted with help of or through the media). Dr. Nerijus Maliukevičius offered an example of how the media can be an instrument of change when he discussed Lithuania's efforts to reduce its high number of suicides. The media was involved in this advocacy campaign as 'advocacy' instrument: when providing suicide-related information, the media always gave hotline numbers so everyone affected could receive confidential help.

Large labor unions in Lithuania learned from their experiences during the Soviet era how to combine their efforts. Groups protecting the LGBT community and advancing gender issues have drawn from Western experiences in learning how to use advocacy instruments. In many instances, LGBT groups were described by interviewees as pioneers of advocacy actions. As reported during interviews, NGOs in Lithuania are often misinterpreted by society as the only advocacy agents.

In Lithuania's pluralistic society and consolidated democracy, advocacy targets may be many: authorities, media, or society at large. According to Anna Gerasimova, the agents of advocacy in Lithuania are people and organizations whose interests and rights are violated (active advocacy). ${ }^{23}$ Thus, individuals and organizations can protect their rights and interests themselves without creating broader alliances.

\section{Goals of Advocacy in Lithuania}

Because of differences in the regimes among Ukraine, Belarus, and Lithuania, priorities for and changes driven by advocacy in Lithuania are somehow different. In contrast to "regime" countries (Belarus) and transitioning countries (Ukraine), Lithuania, as consolidated democracy, does not have a special goal to change its regime or its core policies. Sometimes it has protests that are run like political movements, but these movements do not aim at regime-change. Instead, according to the experts interviewed, they mask the inefficiency of some of the political parties that represent ethnic minorities in Lithuania.

"Savanoriai yra didžiausias "Baltujų pirštineų "turtas," Baltos iospirštinės, accessed April 10, 2020. https://www.baltosiospirstines.lt/savanoryste.

23 Jenkins-Smith, Hank, "The Advocacy Coalition Framework: An Assessment," Theories of the Policy Process (CO: Westview Press 1999): 117-68. 
What is the final goal of advocacy? Is it to change the system? Or is it to motivate civil society? Campaigns on suicides, against taxes, focusing on traffic accidents were scheduled to mainly motivate society, to draw the attention to the social problem, and to make society the agent of change. For example, the campaign on traffic accidents featured various concerns, such as drunk driving, speeding, and insufficient seatbelt use. And it influenced society and motivated it to pay special attention to the level of safety on the road. According to the experts interviewed, civil society lacks the will to implement advocacy. On individual level, people in Lithuania may decide to move to another country rather than change the situation in their own country.

\section{The Level of Advocacy Implementation in Lithuania}

Lithuania used to be very vocal in the Eastern partnership, but no examples of international advocacy (advocacy on international level) were offered during interviews with the Lithuanian experts. Local advocacy is considered more typical for Lithuania. According to Mr. Florian Irminger, "Lithuanian advocacy targets are mainly domestic and not international."

There is a consolidated approach in Lithuanian politics that promotes interests and positions. This makes national advocacy minor and often unnecessary. The availability of this approach contributes to more effective policy advocacy and policy implementation. Events organized by ethnic minorities and gender and LGBT organizations are visible at the national level. In recent years, NGOs registered in Lithuania faced the problem of taxation if they provided services to individuals outside Lithuania (e. g. Belorussian organizations registered in Lithuania and providing services to Belorussian citizens). Representatives of NGOs actively advocate for legislation that may help to turn Lithuania into a donor country by eliminating taxes on international technical aid.

In non-free Belarus, in contrast to Lithuania, the bottom-up pressure is nonexistent. In Belarus, it is almost illegal to advocate as there is no freedom of assembly or association. International advocacy is more effective (top-down approach) than national advocacy (bottom-up approach). Most advocacy targets in Belarus are outside the country. In Florian Irminger's opinion, a particularity of very oppressive regimes is that the international advocacy becomes top-down rather than from the grassroots.

As Mr. FlorianIrminger commented, in a consolidated democracy, society has the opportunity to openly debate any changes in the national system. People do not have to go on strike or take part in demonstrations because their view is considered without the state trying to block it from being heard. Therefore, there is no special need for national advocacy.

\section{Conclusions}

In the sections above, the following characteristics of advocacy are illustrated through interviews with Ukrainian, Belarusian and Lithuanian experts: scale of advocacy, 
advocacy agents and targets, goals of advocacy, advocacy's drawing on the protection of rights and freedoms, the protection of interests and/or the promotion of ideas. Conclusions about these characteristics of advocacy are summarized below.

\section{The Scale of Advocacy}

Advocacy involves many people and often takes the form of civic movements in Ukraine. Advocacy movements in Ukraine have an ideological and anti-corruption character and often aim at protecting interests and ideas. Quite often advocacy is implemented by coalitions that consist of several civil society organizations, and, in instances, it seeks to promote certain reform or to protect the interests of a stakeholder groups. ${ }^{24}$ Advocacy in Ukraine has historical bases such as history of opposition, sharp feeling of injustice in society. Since the 199os Ukraine has experienced multiple politicized and civil advocacy movements. These include the well-known and large-scale movements known as the Orange Revolution and Revolution of Dignity.

Unlike in partly free Ukraine, in non-free Belarus advocacy activities are constrained because of low solidarity potential of the society and often do not lead to any systemic changes. A low solidarity potential of the civil society in Belarus shows indirectly that even if advocacy activities are in place, they involve limited number of people and/or limited to participation of human rights groups. Due to the political situation in Belarus and the repressive character of its legislation, achieving a high level of solidarity is impossible. Civil society organizations in Belarus that assist disabled persons, children, and those who suffered from family violence often refuse to cooperate with human rights groups and refrain from positioning themselves as right-protecting organizations.

In Lithuania, with its "free" freedom regime, advocacy is neither massive nor aggressive. There is little need for advocacy under the conditions of a pluralistic society and consolidated political regime where different groups may promote their own interests. The society has the tools and necessary policies to discuss and promote changes at the national level and such activities do not need advocacy.

\section{The Place of Interests, Values, and Rights in Advocacy}

As the interviewed experts commented, advocacy in modern Ukraine is mainly used to protect interests. There are mechanisms to promote interests and more opportunities for reaching out to representatives of authorities. Before the Revolution of Dignity in Ukraine, when the level of rights and freedoms implementation was lower, the main motivation for advocacy was the protection of rights and freedoms. The protection of interests is sought mostly by the groups whose interests were harmed, e.g., representatives of the agrarian sector, SMEs, and families of participants of the ATO.

Advocacy in Belarus is based on promotion of interests and protection of rights. Advocacy in Lithuania is mainly based on interests, however, in some cases interests 
are deeply connected with values. The protection of interests by ethnic minorities in Lithuania is a politicized process, however, advocacy by other groups remains apolitical.

\section{The Agents and Targets of Advocacy}

Due to changes in the political situation in Ukraine, new agents of advocacy have appeared on the advocacy scene in recent years, i. e., IDPs and veterans of the Anti-Terroristic Operation (previously referred to as "ATO". In the case of national and local advocacy (advocacy at the local level), government bodies often become advocacy targets. In case of international advocacy, government bodies and representatives of authorities act as advocacy agents and participate in international advocacy at the European Court of Human Rights, the Hague Tribunal, and similar judicial bodies.

The agents of advocacy in Belarus are mostly groups of stakeholders whose interests and rights have been violated or who have suffered from a problem. These groups do not always receive support from the civil society or from political or human rights organizations. Selecting advocacy targets in modern Belarus requires detailed analysis that considers the specific nature of the system of governance and the existing authoritarian non-free regime.

Agents of advocacy in "free" Lithuania represent different groups. $\Delta$ They do not need to seek to create alliances with other groups. They only need to advocate for the groups they represent. According to experts interviewed, the advocacy targets are the legal and social environment, government, and civil society.

\section{The Goals of Advocacy}

Achieving changes in Ukraine is difficult and slow because the political will to change is lacking and entrenched corruption erects roadblocks. Improving the quality of life is the most common goal of advocacy activities in Belarus. As the goal and the product of advocacy, systemic changes are almost impossible under the low solidarity in the society and the authoritarian regime. Every attempt to attain systemic changes in notfree Belarus often ends with arrests, including preventive arrests, and the dispersal of peaceful protesters. Advocacy in Lithuania is not aimed at changing the regime or governmental policies; advocacy is often aimed at changing the attitude of society towards certain issues.

\section{The Level of Advocacy Implementation}

The effectiveness of advocacy in Ukraine does not depend on its level of implementation, i. e. local, national, or international. Targets for advocacy implementation are in Ukraine as outside of Ukraine. The national level of advocacy implementation is connected to the development of the national legislation, the creation/promotion of rules and strategies, the drafting of documents on protecting interests of different groups (e. g. National Strategy on Human Rights). Local advocacy is less widespread 
and is connected with the implementation of local ideas, e. g., relocation or ensuring better transparency of local budgets.

The effectiveness of advocacy in not-free Belarus often depends on the level of politicization of the issue in society: the more politicized the issue, the less effective and possible the advocacy is. For example, advocacy aimed at protection of human rights, a politicized issue, may be less effective at the national level and more effective at the international level. The consolidated approach in politics in Lithuania makes national advocacy irrelevant and unnecessary. Advocacy campaigns are mainly implemented at the local level and are related to local issues. During their interviews, the experts did not provide any examples of international advocacy. This demonstrates that advocacy targets are mainly domestic and are in Lithuania rather than outside of it.

Democracy (especially under conditions when the freedom cannot be fully exercised), is impossible without exercising public will, civic activism, and advocacy. Without advocacy, the democracy might have remained a mechanism to elect a government. All advocacy characteristics mentioned in the article have very practical meaning like the ability to pass or block a law, demand actions from power holders, galvanize people around the idea, and work with others to achieve the change. Advocacy characteristics and tools are diverse and vary from aggressive protests to analysis, from grassroot organizing to media work, and from boycotts to social media involvement. Advocacy actors and targets range from young people to experienced opinion makers and from the representatives of the single community to the population at large.

While characteristics of advocacy are related to the changes happening in societies and the level at which political freedoms and civil liberties can be implemented in society, it would be relevant to research how advocacy characteristics evolve within the changes in societies and regimes that become more free and/or experience an outbreak of advocacy.

An analysis of advocacy characteristics proves that advocacy is a very practical thing. Not every advocacy approach as shown in this analysis of advocacy characteristics works equally effectively in the different freedom regimes or across all issues. The analysis of advocacy characteristics under different regimes leads us to the thought that there is not a single way to advocate. While advocacy is not an easy act given advocacy actors, targets, goals, and the like, examining advocacy characteristics in different regimes of freedoms, helps advocacy implementers to understand what it takes to win.

\section{Bibliography}

Baltos iospirštinès. "Savanoriai yra didžiausias "Baltujų pirštineų" turtas.” Accessed April 10, 2020. https://www.baltosiospirstines.lt/savanoryste.

Batsyukova, Svitlana. "Characteristics of Advocacy in Current Belarus. Results of Expert Interviews." Info-bulletin of Lviv University. The series of Philosophy and Political Studies 11 (2017): 111-16.

Batsyukova, Svitlana. "Defining Advocacy as a Subject of Research in Political Science." Info-bulletin of Kharkiv National University. Series "Issues of Political Science" 27 (2014): 77-82. 
Batsyukova, Svitlana. "Freedom Status as a Reflection of Existence of Advocacy in Society" Academic journal "POLITICUS" (2017): 44-46.

Batsyukova, Svitlana. "Motivating Factors for Advocacy in Countries with Different Freedom Statuses: Ukraine and Belarus." The Ideology and Politics Journal: 5-29.

Belarusian Institute of Strategic Studies. The Center of European information. "Research on the potential of solidarity in Belarusian civil society". Accessed April 24, 2020. http://cet.eurobelarus.info/files/userfiles/5/CET/2014_Solidarity_NGOs_Belarus. pdf.

Diuk, Nadia, "Finding Ukraine." Journal of Democracy. The Maidan and Beyond. 25, no. 3 (2014): 83-9o.

Freedom House. "Freedom in the World 2019. Belarus." Accessed April 25, 2020. https://freedomhouse.org/country/belarus/freedom-world/2019.

Freedom House. "Freedom in the World 2019. Lithuania." Accessed April 25, 2020. https://freedomhouse.org/country/lithuania/freedom-world/2019.

Freedom House. "Freedom in the World 2019. Ukraine." Accessed April 25, 2020. https:// freedomhouse.org/country/ukraine/freedom-world/2019.

Freedom House. "Freedom in the World 2019 Methodology." Accessed April 23, 2020. https://freedomhouse.org/sites/default/files/2O2O-O2/Methodology_FIW_2O19_ for_website.pdf.

Jenkins-Smith, Hank, "The Advocacy Coalition Framework: an Assessment." Theories of the Policy Process (CO: Westview Press 1999): 117-68.

Juska, Arunas and Charles Woolfson, "Policing Political Protest in Lithuania". Crime, Law and Social Change no. 57 (2012): 403-24.

Law of Ukraine. "On the Adoption of the National Strategy on Human Rights. [Zakon Ukrayiny. Pro zatverdzhennia Natsionalnoii strategii u sferi prav liudyny]." Accessed April 25, 2020. http://zakon3.rada.gov.ua/laws/show/501/2015.

RU.DELFI. "Protests by the Parliament of Lithuania. What will happen with schools in Vilnius? (Protesty u pravitelstva Litvy. Chto budet so shkolami Vilniskogo kraia?)" Accessed April 27, 2020. http://ru.delfi.lt/news/live/protest-u-pravitelstva-litvychto-budet-so-shkolami-vilnyusskogo-kraya.d?id=68125716.

Sokolova M., "Advocacy democracy modes: Benefits and limitations." Informacijos Mosklai (2014): 110-21.

The Mayor.EU. "Take part in "Let's do it" initiative to clean up Lithuania in a day!" Accessed April 9, 2020. https://www.themayor.eu/en/take-part-in-lets-do-itinitiative-to-clean-up-lithuania-in-a-day.

Talaka. "Seven Facts about Talaka [Sem faktov o Talaka]." Accessed April 25, 2020. https://www.talaka.org/.

Ukrainska Pravda. "Arrests are Happening Again in Minsk." Accessed April 24, 2020. http://www.pravda.com.ua/news/2017/03/26/7139323/.

Ukrainska Pravda. "Freedom Day in Belarus: Militia Fills in Autozaks with Arrested." Accessed April 25, 2020. http://www.pravda.com.ua/news/2017/03/25/7139266/.

UNHCR. "Nations in Transit 2018. Lithuania." Accessed April 27, 2020. https://www. refworld.org/docid/5b3cc27fa.html. 
Jonathan M. Tisch College of Civic Life. "Civic Leaders explore the Frontiers of Democracy". Accessed April 23, 2020. https://tischcollege.tufts.edu/news/civic-leaders-explore-frontiers-democracy.

United Nations Human Rights Office of the High Commissioner. "Belarus: unchanged oppression of human rights necessitates continuation of UN mandate, Special Rapporteur says." Accessed November 28, 2018. http://www.ohchr.org/EN/ NewsEvents/.

\section{(7)}

Svitlana Batsyukova is a World Bank Consultant in Ukraine. She has over 14 years of academic and professional experience in Ukraine, the EU, and the USA. She developed and taught "Advocacy in Society" at Vilnius University, in Vilnius, Lithuania, and "Advocacy and Human Rights" at the Ukrainian Catholic University, in Lviv, Ukraine. She has also taught over 30 seminars on advocacy at Ukrainian universities. In 20152016, Ms. Batsyukova pursued her research on motivation factors and characteristics of advocacy at Vilnius University as a part of her PhD studies. In 2011-2015, as an advocacy expert, she has trained human rights activists, journalists, community leaders, and young people, and coached advocacy initiatives in Ukraine. She is the author of over 20 publications on advocacy. 


\title{
Характеристики Адвокації за Різних Режимів Свободи: Білорусь, Україна та Литва
}

\section{Світлана Бацюкова}

Консультант Світового Банку, Україна

\begin{abstract}
Анотація
Ця стаття присвячена порівняльному аналізу характеристик адвокації у трьох країнах з різним рівнем політичної та громадянської свободи. Цей аналіз проводить паралелі між рівнем свободи в кожній країні з характеристиками ії адвокаційних активностей. Результати аналізу базуються на проведених інтерв'ю з експертами, здійсненими 32015 по 2017 рік у невільній Білорусі, частково вільній Україні та вільній Литві. Аналіз охоплює такі характеристики адвокації як їі обсяг, агентів, об'єкти, їі цілі, межі, до яких вона використовується для того, щоб захистити права, свободи та інтереси та результати цих дій.
\end{abstract}

Ключові слова: адвокація, статус свободи, характеристики адвокації, Україна, Литва, Білорусь 